\title{
Monitoring Environmental and Health Impact Data in BIM Models to Assure Healthy Living Environments
}

\author{
Anja Jutražl ${ }^{1}$, Andreja Kukec ${ }^{2}$, Peter Otorepec ${ }^{3}$, Ladi Lampič ${ }^{4}$, \\ Jure Pohleven ${ }^{5}$, Jakub Sandak ${ }^{6}$, Katja Malovrh ${ }^{7}$, \\ Monika Varkonji Sajn ${ }^{8}$ \\ ${ }^{1,3,4}$ National Institute for Public Health ${ }^{2}$ University of Ljubljana, Faculty of Medicine \\ and National Institute for Public Health ${ }^{5,6}$ InnoRenew $\mathrm{CoE}^{7}$ Slovenian National \\ Building and Civil Engineering Institute ${ }^{8}$ Zavod eOblak \\ Ianja@jutraz.com²andreja.kukec@mf.uni-lj.si ${ }^{3}$ peter.otorepec@nijz.

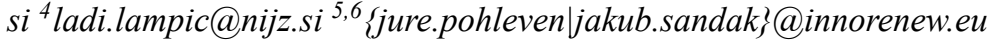 \\ ${ }^{7}$ katja.malovrh@zag.si ${ }^{8}$ monika.varkonji@unistarpro.si
}

\begin{abstract}
Health is our wealth and we are rarely aware that the choice of living and working environment affects us. We spend most of our time in indoor environments so the quality of indoor air plays an important role in the maintenance of health and well-being. Moreover, Building Information Modeling (BIM) is emerging technology, which plays an essential role in collaboration among multi-discipline professions, time and cost saving, fabrication and construction as well as facilities management. However, it is not accepted by all planners yet. BIM could also offer a framework to help improving health and well-being of future users of the new building. The main aim of this paper is to monitor environmental and health impact data in BIM models to assure healthy living environments. First, the paper explores which environmental and health parameters could be measured in the indoor environment and which are already present in BIM models. Second, it explores options to expand BIM specifications to support monitoring environmental and health impact data in BIM models to assure healthy living environments.
\end{abstract}

Keywords: Building Information Modeling (BIM), environmental impact data, indoor comfort, health impact data, healthy living environment

\section{INTRODUCTION}

Health is our wealth and we are rarely aware that the choice of living and working environment affects us. Different environmental elements have influence on human health. On one side we have chemical (environmental pollutants, contaminants in food, pharmaceutical, intoxicant, hazardous substances etc.), biological (microorganisms, plants, animals and foods etc.) and psycho-social influences (living and working conditions, stress, depression 
etc.) and on another side physical influences (climate, weather, heat, cold, radiation, light, color, noise, materials etc.), which mostly result from built environment (Figure 1). Nowadays we spend most of our time in indoor environments so the quality of indoor air plays an important role in the maintenance of health and well-being. Indoor air pollutants can cause different respiratory and cardiovascular diseases and premature deaths (WHO 2002). Also, other indoor risk factors like noise, moulds etc. could have influence on human health and well-being.

Automatization, digitalization and smart technology are significantly changing living in houses, where comfort goes in parallel with energy saving and sustainability (for example there are possibilities to automatically regulated light, window curtains, music in the background etc.). Lately BIM plays an essential role in collaboration among multi-discipline professions, time and cost saving, fabrication and construction as well as facilities management. More and more, BIM models are also integrating the impact of buildings (their entire life cycle) on the environment. However, it is usually used only between architects, structural engineers and MEPs, public health experts are usually not involved in the planning/design process. When planning and designing new living environment, planners and users usually do not pay enough attention to the environmental and health impact data that have influence on wellbeing and indoor comfort.

\section{RESULTS AND DISCUSSION}

The main aim of this paper is to monitor environmental and health impact data in BIM models to assure healthy living environments, while focusing on indoor air quality. As a case study a 100-years old house in Bled, Slovenia, which has been unoccupied for the last 40 years, was chosen.

First, different environmental and health parameters were explored. Based on this, new sensors measuring indoor air quality were proposed and a prototype is under development. Figure 2 presents our approach for implementation of different environmental and health parameters into BIM models. Data, col- lected with physical sensors, will be stored in cloud, and based on these data we could prepare simulations and predict various situations in virtual models of new buildings, using virtual sensors.

\section{Environmental and health impact data as a new BIM specification}

Based on the literature review, building information modeling are already offering:

- environmental performance analysis: indoor air quality, thermal comfort, energy efficiency, moisture comfort, acoustic comfort, light comfort (Sulaihi et al. 2015),

- indoor air quality evaluation: chemical air composition, heat transfer, non-isothermal considerations, detailed flow pattern, overall air distribution (Natephra et all. 2017),

- thermal/energy: energy use, thermal analysis, heating/cooling loads, ventilation and airflow, comfort analysis; visual/shading: solar analysis, daylighting - illuminance; acoustic (Lim 2015),

- thermal comfort, indoor air quality and visual comfort (Sulaihi et al. 2015),

- connections with sensors that can detect variations in temperature and humidity (Marzoul et al. 2015).

Environmental and health data is usually not analyzed in one program or one 3D model, but in different simulation tools. With this research we want to explore the possibilities how different parameters could be monitored with sensors and how the data could be available for and used by planners. Groups of environmental and health impact data, that should be linked together in BIM models, are:

- indoor air quality,

- thermal comfort,

- light comfort,

- acoustic comfort,

- materials,

- health data (evidence based data from literature review). 
Figure 1

Different influences

from built

environment on

human health (2)
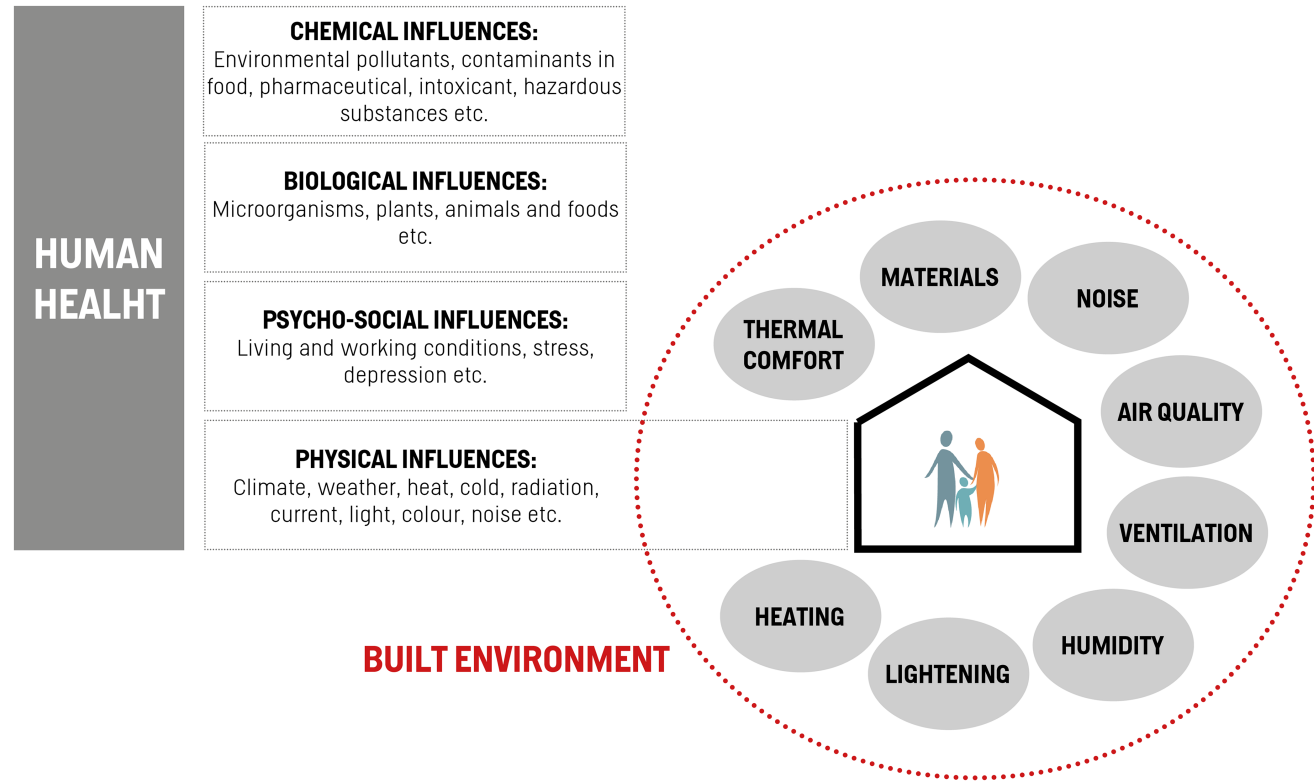

As this is a complex data, our research is focused only on indoor air quality assessment. Nowadays we spend most of our time in indoor environments so the quality of indoor air plays an important role in the maintenance of health and well-being (Giulio et al. 2009). Indoor air pollutants can cause different respiratory and cardiovascular diseases and premature deaths (WHO 2002).

\section{Surface temperature and relative humidity on a} wall. The conditions at the exterior surface of building components with high insulation are almost independent of the indoor climate. The tiny heat flow from the interior is generally not sufficient to prevent a temperature drop below ambient conditions by long-wave emission during night time. Apart from energetic consequences, this temperature drop may lead to surface condensation and subsequently to soiling or microbial growth. Another factor resulting in surface temperatures below ambient conditions is the evaporation of precipitation moisture (Kunzel et

\section{al. 2002).}

Moulds in the indoor environment. Moulds are multicellular fungi that are ubiquitous in indoor and outdoor environment. Exposure to moulds can occur through inhalation, ingestion, and touching mouldy surfaces. Adverse health effects may occur through allergic, infectious, irritant, and toxic processes. Epidemiological studies all over the world have shown that mould sensitivity is associated with the development, persistence and severity of asthma and other respiratory allergic diseases. Recent studies suggest that host immune response to environmental moulds and genetic factors may play an important role in the development of allergic respiratory diseases. This new knowledge could help us to prevent and cure these diseases. There are also studies about the potential toxic reactions to mycotoxins (Perčič et al. 2017). 


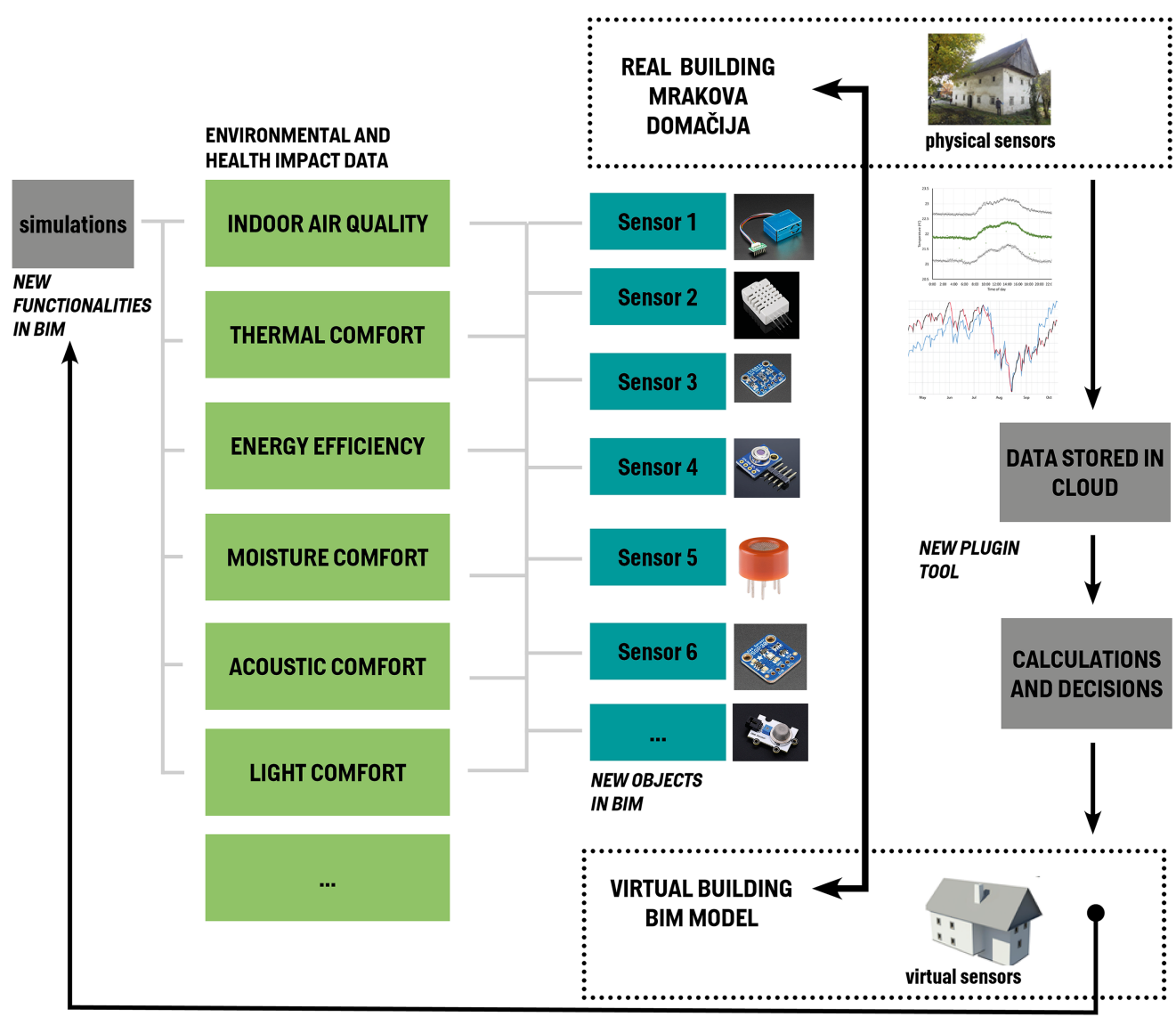

Figure 2

Approach for

implementation of different

environmental and health parameters into BIM models

based on collected physical data from our case study we could predict situations in other virtual buildings using virtual sensors data stored in cloud is based for simulations 
Table 1

Parameters that should be measured with sensors in our study
Odour in the indoor environment. The presence of pleasant or unpleasant odours can strongly influence the environmental comfort. Odour nuisance may also have direct and indirect impacts on heath. Among the symptoms caused by unpleasant odours are the symptoms of classical stress response, nausea, fatigue, irritations (eyes, nose, throat), sleep disturbance and inability to concentrate (Badach et al. 2018, Eusebio et al. 2017, Nicell 2009, McGinley et al. 1999).

To be more specific, in the new buildings following health parameters should be included in BIM models for indoor air quality assessment: air temperature, relative humidity, carbon dioxide, carbon monoxide, nitrogen dioxide, ozone, PM2.5 mass concentration, particle number concentration ultrafine particles, radon, air exchange rate, dust, aldehydes: formaldehyde, acetaldehyde, acroleine, propionaldehyde, benzaldehyde, hexanal, glutaraldehyde, VOCs: benzene, toluene, xylenes, ethylbenzene, n-

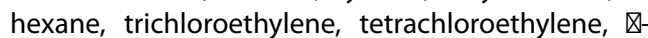
pinene, limonene, 2-butoxyethanol, 2-ethylhexanol, styrene, naphthalene.

Additionally, in the renovation buildings following health parameters should be included in BIM models for indoor air quality assessment: air temperature, relative humidity, surface temperature, surface relative humidity, mould, $\mathrm{CO} 2, \mathrm{CO}$, radon and particle matters.

Our case study is renovation building; therefore, we will explore more in detail only parameters that could be present in renovation buildings. Unlike other studies, we are interested in how we could develop sensors for a more complex analysis that would not only contain basic parameters but some more specific ones (Table 1).

According to national legislation (Uradni list RS, št. 99/99) (1) limit values for these parameters, which should be part of BIM plugin (new BIM specifications), are:

- Air temperature: outside the heating season between $22^{\circ} \mathrm{C}$ and $26^{\circ} \mathrm{C}$, recommended $23^{\circ} \mathrm{C}$ to $25^{\circ} \mathrm{C}$; heating season between $19^{\circ} \mathrm{C}$ and 24
${ }^{\circ} \mathrm{C}$, recommended $20^{\circ} \mathrm{C}$ to $22^{\circ} \mathrm{C}$

- Relative humidity: under $60 \%$

- Surface temperature: maximum radiative temperature asymmetry: for a cold wall $<13$

${ }^{\circ} \mathrm{C}$, for a warm wall $<35^{\circ} \mathrm{C}$, for a cold ceiling $<$ $18^{\circ} \mathrm{C}$, for a warm ceiling $<7{ }^{\circ} \mathrm{C}$.

- Mould: not be present in building construction

- VOCs: $600 \mu \mathrm{g} / \mathrm{m} 3$

- CO2: $3.000 \mathrm{mg} / \mathrm{m} 3$

- CO: $10 \mu \mathrm{g} / \mathrm{m3}$

- Radon: $400 \mathrm{~Bq} / \mathrm{m3}$, recommended $200 \mathrm{~Bq} / \mathrm{m} 3$

- Particle matters (PM10): $100 \mu \mathrm{g} / \mathrm{m} 3$

Criteria was defined based on Rules on ventilation and air conditioning of buildings (Uradni list RS, št. 99/99) (1).

\begin{tabular}{|l|l|l|}
\hline $\begin{array}{l}\text { PARAMETER FOR } \\
\text { INAIRQ }\end{array}$ & LOCATION & $\begin{array}{l}\text { Level of possibility } \\
\text { for its } \\
\text { implementation } \\
\text { into BIM models }\end{array}$ \\
\hline Air temperature & Indoor & Easy \\
\hline Relative humidity & Indoor & Easy \\
\hline Surface temperature & Indoor & Easy \\
\hline $\begin{array}{l}\text { Surface relative } \\
\text { humidity }\end{array}$ & Indoor & Easy \\
\hline Mould & $\begin{array}{l}\text { Indoor (visual } \\
\text { assessment), but we } \\
\text { don't identify the } \\
\text { type of molds } \\
\text { (specific } \\
\text { microbiological } \\
\text { analysis) }\end{array}$ & Hard \\
\hline Odour & Indoor & Not possible \\
\hline Mould VOCs & indoor & Hard \\
\hline $\mathrm{CO}_{2}$ & Indoor & Easy \\
\hline $\mathrm{CO}^{\text {Indoor (if there is an }}$ & Easy \\
\hline Radon & $\begin{array}{l}\text { Indoo black kitchen) } \\
\text { active }\end{array}$ & Hard \\
\hline Particle matters (PM) & indoor & Easy \\
\hline
\end{tabular}

\section{NEW SENSORS FOR MEASURING INDOOR CONDITIONS}

The article focuses also on development of new physical and virtual sensors for measuring indoor conditions. The measured data will be integrated with BIM models in order to track and improve the problems, and to develop history over time. Our aim is to de- 


\section{EXAMPLES OF SENSORS FOR MONITORING ENVIRONMENTAL AND HEALTH DATA}

\begin{tabular}{l|l} 
sensor type & measured property \\
\hline$M Q-2$ & combustable gass, smoke \\
\hline$M Q-3$ & alkohol \\
\hline$M Q-4$ & methane, propane, butane \\
\hline$M Q-5$ & butane, propane, methane \\
\hline$M Q-6$ & liquified petroleum, butane, propane, LPG \\
\hline$M Q-8$ & carbon monoxide \\
\hline$M Q-9$ & hydrogen \\
\hline$M Q-131$ & carbon monoxide, methane \\
\hline$M Q-135$ & ozone \\
\hline$M Q-136$ & ammonia, sulfide benzene vapour \\
\hline$M Q-137$ & sulfur dioxide \\
\hline$M Q-138$ & aminia \\
\hline$D H 22$ & organic steam \\
\hline$P M 2.5$ & temp, RH \\
\hline$C C 811$ & air quality, particle size \\
\hline$M L X 90614$ & air quality, VoC, C02 \\
\hline$M$ & IR thermometer (surface temperature) \\
\hline$M$
\end{tabular}

Figure 3

Different real-life

sensors for

monitoring

environmental and health parameters velop sensors that combine all sensors that were explained in previous chapter.

Measurements should be done in rooms where people dwell for longer periods of time (e.g. living rooms, bedrooms, classrooms, nursery school rooms and office rooms). In private dwellings, a choice may have to be made between the living area and the sleeping area.

The sensor should be placed at least $1 \mathrm{~m}$ to $2 \mathrm{~m}$ from a wall and at a height of 1,50 $\mathrm{m}$ or $1 \mathrm{~m}$ to $1,2 \mathrm{~m}$ in case of offices, schools or kindergartens where the sitting position is normal. Locations close to strong sources should be avoided. Places in the sun, close to heating systems, with noticeable draught or close to ventilation channels and near an open window area should be avoided, because this may influence the measurement results. Preferable sensors should be placed on inner wall ( $5 \mathrm{~mm}$ away from the wall) and avoided from other adverse conditions in the indoor environment (not installed there): too high humidity of the wall, floor, ceiling; dust; strong vibrations etc.

Based on these criteria for defining micro- and macro- location of indoor air quality sensors algorithms will be developed and integrated into BIM plugin.

Figure 3 presents some options of different reallife sensors for monitoring environmental and health parameters.

\section{NEW APPROACH TO ASSURE A HEALTHY LIVING ENVIRONMENT}

Figure 4 shows how BIM model (digital twin of realworld building) offers possibility for health assessment of old/new buildings:

- Involvement of different stakeholders, from AEC professionals to public health experts;

- Use through the entire design process, from 
Figure 4

New approach for implementation of different environmental/ health parameters into BIM models
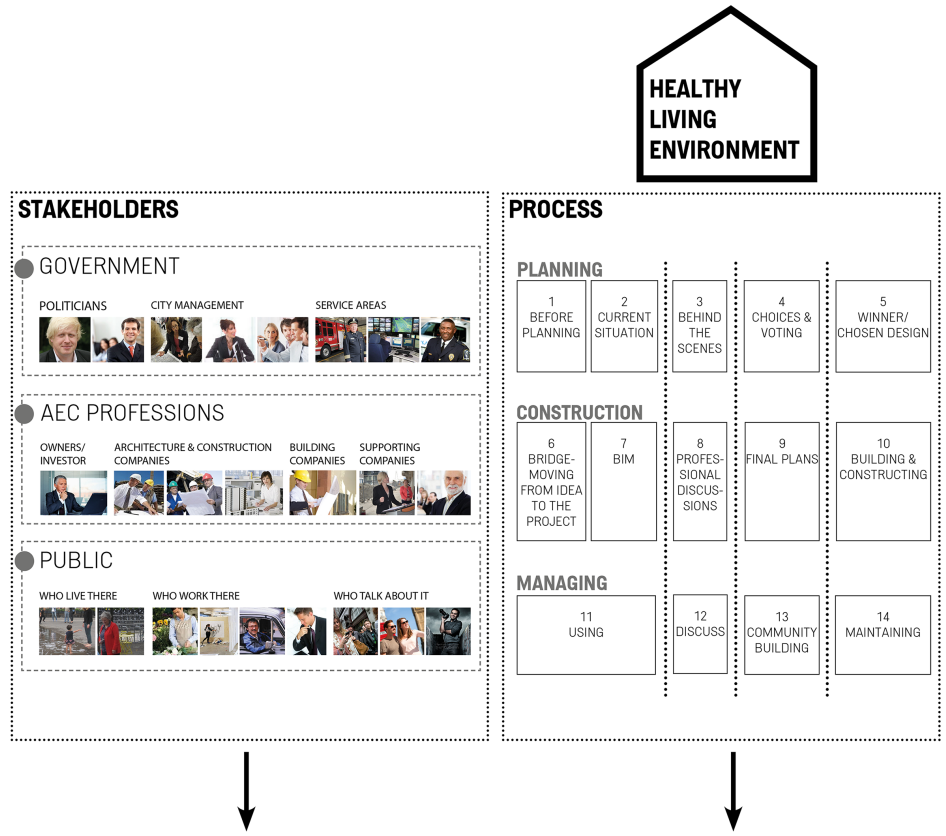

ENVIRONMENTAL \& HEALTH DATA INDOORAIR PARTILCE MATTERS VENTILATION THERMAL COMFORT

HEATIN HUMIDITY ENERGY AIR
EFFICIENCY HUMIDITY TEMPERATURE \begin{tabular}{llc} 
MOISTURE & AIR \\
\hline COMFORT & HUMIDITY \\
\hline & TEMPERATURE
\end{tabular}

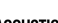
COMFORT

NOISE LIGHT BUILDING \begin{tabular}{l} 
COMFORT LOCATION \\
\hline
\end{tabular} MATERIALS ALDEHYDES

\section{TOOLS - BIM MODELS}

USING BIM MODELS FOR INTERDISCIPLINARY COLLABORATION THROUGH THE ENTIRE DESIGN PROCESS (FROM PLANNING TO MAINTAINING), MONITORING COLLECTING, ANALYSING, STORING ENVIRONMENTAL AND HEALTH DATA IN BIM MODELS (PLUG IN, DATA STORED IN CLOUD, ADDITIONAL SOFTWARES FOR SIMULATION)

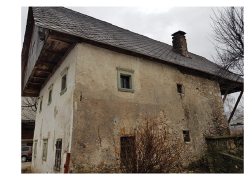

REAL WORLD

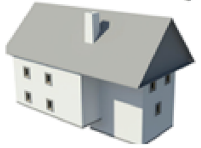

DIGITAL TWIN IN VIRTUAL WORLD planning to maintaining phase;

- Implementation of different environmental and health parameters.

Data stored in cloud will be used when designing new buildings, as simulations and predictions will be done in digital twins before even the building will be built. The collected data will be used also for other projects, as the new BIM plugin will offer simulations of environmental and health data when designing new house.

\section{CONCLUSION AND FUTURE WORK}

To conclude, BIM could offer a framework to help improve health and well-being of future users of new building. With this paper we wanted to show the possibilities of connected different health and environmental data in BIM model in order to assure healthy living environment. Moreover, BIM could be used as a platform for interdisciplinary collaboration between different stakeholders (where also public health experts should be involved) at different stages of design process (from planning to maintaining). 
Measurement campaign (indoor air assessment in real building), which is base for our further research on new plugins for BIM models, was moved to summer 2019 due to technical problems with sensors. Future work presents development of new BIM plugin. Research on monitoring, collecting, analyzing and storing environmental and health data in BIM models will be discussed in next paper.

\section{ACKNOWLEDGMENTS}

The research presents part of project "Development of plugin for the test environment Revit that will use new BIM element entities in the model", which was formed by the Slovenian National Building and Civil Engineering Institute (ZAG), as project leader, and project partners from the InnoRenew $\mathrm{CoE}$, University of Primorska (UP), Institute for the Protection of Cultural Heritage of Slovenia (ZVKDS), Slovenian National Institute of Public Health (NIJZ) and Institute eOblak. It was founded by the Horizon 2020 Framework Programme of the European Union; H2020 WIDESPREAD-2-Teaming; 739574.

\section{REFERENCES}

Badach, J, Kolasińska, P, Paciorek, M, Wojnowski, W, Dymerski, T, Gębicki, J, Dymnicka, M and Namieśnik, $J$ 2018, 'A case study of odour nuisance evaluation in the context of integrated urban planning', J Environ Manage, 1(213), pp. 417-424

Eastman, C, Teicholz, P, Rafael, S and Liston, K 2008, BIM Handbook, John Wiley \& Sons, Inc., New Jersey

Eusebio, L, Derudi, M, Capelli, L, Nano, G and Sironi, S 2017, 'Assessment of the Indoor Odour Impact in a Naturally Ventilated Room', Sensors (Basel), 17 (4), p. 778

Giulio, M, Grande, R, Campli, E, Bartolomeo, S and Cellini, L 2009, 'Indoor air quality in university environments', Environ Monit Assess, 170(1-4), p. 509-17

Kunzel, HM, Schmidt, Th and Holm, A 2002 'Exterior Surface Temperature of Different Wall Constructions Comparison of Numerical Simulation and Experiment', Proceedings 11. Symposium for Building Physics, TU Dresden, pp. 441-449

Lim, YW 2015, 'Building information modeling for indoor environmental performance analysis', American Journal of Environmental Sciences, $11(2)$, pp. 55-
61

Marzoul, MM, Abdelbasset, IG and Gahtani, KA 2015 'Tracking indoor air quality of building using BIM', 5th International/ 11th Construction Specialty Conference, Vancouver, British Columbia

McGinley, MA and McGinley, CM 1999 'The grey line 'between odour nuisance and health effects', Proceedings of Air and Waste Management Association 92ndAnnual Meeting and Exhibition

Natephra, W, Motamedi, Al, Yabuki, N and Fukuda, T 2017, 'Integrating 4D thermal information with BIM for building envelope thermal performance analysis and thermal comfort evaluation in naturally ventilated environments," Building and Environment, 124, pp. $194-208$

Nicell, JA 2009, 'Assessment and regulation of odour impacts', Atmos. Environ., 43, pp. $196-206$

Perčič, S, Otorepec, P and Kukec, A 2015, 'Plesni v notranjem okolju in možni učinki na zdravje: Moulds in the indoor environment and possible health effects', Zdrav Vestn, 84, pp. 820-33

Sulaihi, Al, Gahtani, Al, Alsugair, A and Tijani, I 2015, 'Assessing Indoor Environmental Quality of Educational Buidlings Using BIM', Journal of Environmental Science and Engineering, B 4, pp. 451-458

WHO, / 2002, The world health report 2002: Reducing risks, promoting healthy life, World Health Organization, Geneva, Switzerland

[1] https://www.uradni-list.si/glasilo-uradni-list-rs/vsebi na/36371\#

[2] https://cgi.tu-harburg.de/囚awwweb/wbt/emwater/l essons/glossary/term_138.html 